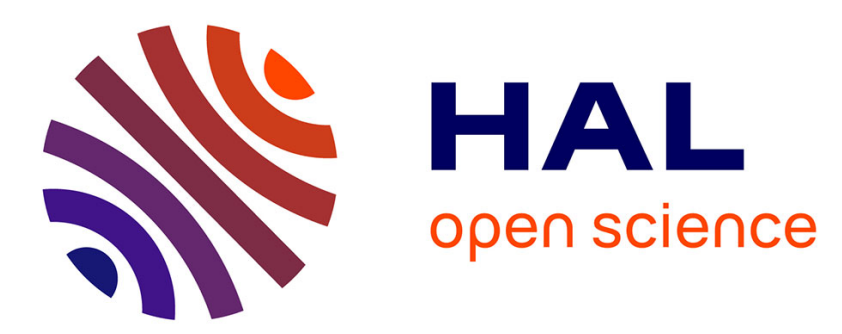

\title{
Managing Marginality in Railway Stations: Beyond the Welfare and Social Control Debate
}

François Bonnet

\section{To cite this version:}

François Bonnet. Managing Marginality in Railway Stations: Beyond the Welfare and Social Control Debate. International Journal of Urban and Regional Research, 2009, 33 (4), pp.1029-1044. halshs00879313

\section{HAL Id: halshs-00879313 \\ https://shs.hal.science/halshs-00879313}

Submitted on 2 Nov 2013

HAL is a multi-disciplinary open access archive for the deposit and dissemination of scientific research documents, whether they are published or not. The documents may come from teaching and research institutions in France or abroad, or from public or private research centers.
L'archive ouverte pluridisciplinaire HAL, est destinée au dépôt et à la diffusion de documents scientifiques de niveau recherche, publiés ou non, émanant des établissements d'enseignement et de recherche français ou étrangers, des laboratoires publics ou privés. 


\title{
"Managing Marginality in Railway Stations: Beyond the Welfare and Social Control Debate" \\ Francois Bonnet
}

International Journal of Urban and Regional Research, 33 (4), 2009, pp. 1029-1044

Keywords: poverty - railway stations - welfare - social control - police - NGO agency - homeless - community organizations

\begin{abstract}
How to rid railway stations of the marginalized people who congregate in them? This is the problem faced by railway companies which are seeking to maximize the attraction of their spaces. The limitations of a strictly repressive policy are leading railway companies to fund non-profit community based organizations to carry out social policies aimed at the marginalized. Based on two monographs in the railway stations of Lyon and Milan, the article analyzes how this strategy was implemented. The analysis requires a distinction to be drawn between two conceptions, one which sees social policies and security policies as polar opposites, and the other which identifies them with one another. The work of the non-profit community-based organizations shows that the boundary between social policy and security policy is a tenuous one, since the principal aim is to disperse the marginalized and move them away from the station. Control of the marginalized is based on the use of incentive structures rather than on coercion. The organizations also have to retain control of their philanthropic legitimacy, which they are selling to the railway companies, but which they are also putting at risk. Attention to the agency of the actors allows us to avoid an irenic analysis (in which "human" and "just" social policies come to the aid of the marginalized) and a malefic analysis (in which social policies are merely security policies in disguise).
\end{abstract}




\section{Managing Marginality in Railway Stations: Beyond the Welfare and Social Control Debate ${ }^{1}$}

Keywords: poverty - railway stations - welfare - social control - police - NGO agency - homeless - community organizations

\section{Introduction: railway stations in cities and the problem of marginalized people}

Railway stations are miniature cities within cities: tens of thousands of travellers pass through them every day, creating a meeting point for a diverse range of populations. They are strategic places in the management of urban and regional flows. The railway stations of the 19th century were closely controlled by a state obsessed by a fear of crowds (Bowie 1996). Only travellers had the right to enter these spaces, and they had to wait for their train in fenced-off waiting rooms (Ribeill 1996). In short, railway stations pose the classic problem of social order in the city. The throughput of travellers makes relationships particularly impersonal. Disturbances are dealt with a minimal level of informal regulations, and travellers remain onlookers upon problems which do not directly concern them. Nowadays, railway stations are open public spaces with shops, and as a result they attract the marginalized. Homeless people, beggars and vagrants pose a dual problem for railway companies. On the one hand, the sight of poverty is bad for business. Railway stations can be frightening and discourage people from travelling by train. The profitability of shops in railway stations is reduced when travellers do not feel at ease. Marginalized people who beg in a rather aggressive way give rise to complaints. On the other hand, the majority of travellers feel compassion for people reduced to begging, and they will not stand for poor people being ill-treated in front of them. Railway stations are public spaces, which prevents the railway companies from controlling access to them and from carrying out purely repressive policies against the marginalized.

In this article, I analyze the way in which two railway companies, in Lyon and Milan, have tackled the problem of marginalized people in their stations. How did the French company (SNCF) rehouse a group of homeless people between 1998 and 1999, and how did the town council and the Italian company $\left(\mathrm{FS}^{2}\right)$ come to favour the work of social workers over that of the police between 1993 and 2004?

\footnotetext{
${ }^{1}$ Translated from French by Gilla Evans. Thanks to Hugo Bertillot, Ayda Hadizadeh, Marie-Pierre Hamel, Patrick Le Galès, Naïma Makri, Olivia Nicol and Julie Pollard, who gave useful feedback on earlier drafts. The paper has been presented at the CERSA (CNRS) seminar and the ENS Cachan conference "Action publique et mobilisations face aux populations mobiles 'indésirables"'. Special thanks to Clément Théry, whose unusual sharpness proved (again) immensely useful.

${ }^{2}$ In Italy, the historical national railway company is Ferrovie dello Stato (FS). FS became a holding company which combined two bodies, Rete Ferroviaria Italiana (RFI) and Trenitalia. RFI manages the infrastructure (the railway network) and Trenitalia operates the trains. In practical
} 
In 1998, in Part-Dieu railway station in Lyon, station users and tradesmen complained of the presence of homeless people, their alcoholic outbursts and their dirtiness. The SNCF planned to have these marginalized people removed by its internal security service, but an executive suggested that they call on the services of a charitable organization which he had heard of in the press. In collaboration with the Ministry of Health, the municipality, the station's trade organization and the police, the SNCF funded an expert's report and a rehousing initiative. The social workers of the organization contacted produced the expert's report and carried out the initiative. The homeless were rehoused and did not return to the railway station.

In the early 1990s three types of marginality were to be found in the Stazione Centrale of Milan: the conventional homeless, drug addicts and newly arrived immigrants. In 1991, the closure of the station at night drove these marginalized people out onto the square and onto the tracks. A number of homeless people died of cold and several drug addicts died of an overdose. Conflicts broke out between Moroccan and Albanian immigrants. The railway station became the very symbol of insecurity. Between 1993 and 1999, the problems of criminality and marginality met with an essentially repressive response on the part of the police. But the persistent presence of drug addicts and homeless people continued to detract from the station's reputation and damage the ambitions of the FS for its commercial renewal. In view of attacks in the press and the discontent of citizens' committees ${ }^{1}$, a deputy at the municipality decided to experiment a new kind of management of the marginality. In partnership with the municipality, the FS invited community organizations which carry out social programs to bid for funding. The railway station became known locally as "a supermarket for assistance". Colombo and Navarini (1999) counted around a hundred voluntary workers in the health and social spheres at the Stazione Centrale in 1999. The profusion of organizations in the precincts of the railway station risked overall disorganization. To provide a coordinating body, the city opened a Help Center with its own office at the station, open to everyone, to streamline the offer of accommodation, food and blankets, with a view to making things easier for marginalized people faced with a fragmented offer of services. The results were convincing: drug addicts were given support, and some of the homeless and immigrants were relocated into disused warehouses belonging to the FS, out of the sight of station users.

In both cases, the community organizations and their partners implemented social policies, both to disperse the marginalized people and to avoid their being subjected to repression pure and simple. These strategies were designed in consultation with the railway companies, which are confronted with

terms, RFI sells Trenitalia time slots in which the trains can operate. RFI also uses service providers to run the stations: Grandi Stazioni operates the thirteen largest Italian stations.

${ }^{1}$ Citizens' committees are locally based associations largely comprising men in stable professional employment. With the legitimacy conferred on them by their status as a group of respectable citizens, they formulate demands to the municipality and institutions, generally on the subject of criminality and immigration. Their image is strongly associated with the parties furthest to the right of the Italian political spectrum (Lega Nord, Alleanza Nazionale), but research on the ground tends to show that the members of these committees are not so much associated with these parties as being exploited by them (Della Porta and Andretta 2001, Poletti 2003). 
the fundamental ambivalence of travellers towards marginalized people, a mixture of rejection and compassion. From a theoretical point of view, analyzing the policy implemented involves moving away from two hypotheses, the irenic hypothesis which regards social policies and security policies as opposing one another, and the malefic hypothesis which identifies them with one another (1). In railway stations, the limitations of police action and the unintended consequences of social policies require the coordination of actors with different values (2). The community organizations are funded by the municipalities and railway companies to carry out a particular service: the control of marginalized people (3). The community organizations are not however mere instruments: they have to take care of their legitimacy and they are able to use the security concerns of their employers for their own ends (4). The conclusion stresses how an analysis in terms of power relations which highlights the agency of the actors (especially of the community organizations) enables us to go beyond the opposition between the irenic and malefic hypotheses (5).

\section{Mechanisms for social order in urban areas}

What is the rationality of the institutions that fund third sector organizations to work on dispersing marginalized people in railway stations? The literature reveals two types of response. For the first type of response, the organizations are welfare providers and the use of charitable organizations occurs in the context of privatization of the welfare state. Social policies that would once have been carried out by the public authorities are now carried out by private organizations. Public authorities, subject to budgetary constraints, fund community organizations to carry out social policies more cheaply. This is notably the argument of Salamon (1993), O'Looney (1993), Smith and Lipsky (1993), Austin (2003) and Marwell (2004), who analyze the rise in power of the third or voluntary sector as a means of privatizing the welfare state in the United States. Drawing up contracts with community organizations through invitation to tender and fixed-term funding, as well as the use of volunteers by the organizations, brings down costs and allows social policies to be diversified to match the various issues that arise. The debate that follows is essentially normative in nature, and implicitly conveys a positive assessment of the social policies conducted by the state: Salamon (1993) condemns the "commodification" of social aid, while O'Looney (1993) considers that the privatization of social services does not in any case stem only from a conservative logic of reducing the remit of the welfare state: it is also in keeping with a "leftist" critique of heavyhanded state bureaucracy, insensitive to individual cases and which stigmatizes users. In this "leftist" critique of the welfare state, the growth in the role of community organizations in the provision of social services is a solution to these problems related to bureaucracy. Austin (2003) cites some sixty academic references showing how the mechanism of invitation to tender is effective in bringing down costs without reducing the quality of the services, provided that it is possible to place community organizations in competition with one another. This first type of response therefore presupposes that social policies are fundamentally benevolent and preferable to security policies: this is the irenic hypothesis.

For the second type of response, the issue is not the privatization of social policies, but rather the dressing up of security policies as social policies (cf. 
Piven and Cloward 1993): this is the malefic hypothesis. This hypothesis is based on two presuppositions: (i) social policies should and could in theory be legitimate progressive objectives, but are in practice a means of social control; (ii) social control is a means for the dominant class to reinforce its domination. From this perspective, many writers have suggested that the social policies were not conceived with a view to improving the wellbeing of the most destitute, but in order to contribute to the maintenance of social order (O'Connor 1973, Platt 1977, Donzelot 1977, Cohen 1979, Offe 1984). For Piven and Cloward (1993), the ultimate aim of the social policies is to prevent disturbances and riots, and to reinforce the work ethic favourable to capitalism (for a critique: Durman 1973, Trattner 1983, Van Krieken 1991 and Dodenhoff 1998). Like the debate on the privatization of social policies, this issue conceals a high potential for political polarization. The discussion risks focusing on the essentialist problem of knowing whether such a social policy is (or is not) social control, a discussion which will be determined a priori by the way in which either camp constructs what it understands by "social policy" and "social control". To get away from this aporia, this article proposes not to look at the question of the essence (social policy versus security policy) but rather to look at the subjective meaning these categories have for the actors, in order to inquire into the specific mechanisms implemented towards marginalized people by the community organizations.

From the point of view of the actors, the opposition between social policy and security policy is very meaningful: this opposition has emic relevance. From the conservative point of view, security policies are associated with efficiency and authority, while social policies are associated with "do-gooders" and excessive tolerance; and marginalized people are criminals or nuisances. From the progressive point of view, social policies are associated with humanism and justice, while security policies are associated with repression and violence; and marginalized people are victims. The police tend to value security policies, while social workers value social policies. From the point of view of sociology, from an etic point of view, the dichotomous opposition between social policy and security policy in practice has to be challenged. Taking account of what is meaningful for the actors enables us to reconstruct their rationalities; not using these oppositions as categories of analysis enables us to describe the mechanisms for managing marginalized people and the interactions between the organizations and their employers. By getting away from the essentialist opposition between security policy and social policy, we give ourselves the means to take account of the power relationships, the agency ${ }^{1}$ of the actors, their local margin of manoeuvre, and their capacity to exploit their interactants. Such a strategy should make it possible to avoid both the irenic vision (in which "human" and "just" social policies come to the aid of marginalized people) and the malefic vision (in which social policies are nothing more than security policies in disguise).

\footnotetext{
${ }^{1}$ The notion of agency is used in two registers: the theoretical question of the relationship between association and agency (Sewell 1992, Emirbayer and Goodwin 1994, Emirbayer and Mische 1998), and the theory of the principal-agent (also known as agency theory) (Shapiro 2005). In this paper, the notion of agency refers to the idea that most of the time the actors refuse to be a simple means at the service of exogenous ends, and that they retain, even in asymmetrical relationships, a margin for manoeuvre which they know how to make use of (Crozier and Friedberg 1977, Friedberg 1993) because they are fundamentally endowed with "self-interest (with guile)" (Williamson 1975).
} 
Methodology: a study in two stations

The empirical work that underpins this analysis is based on two monographs carried out in the Part-Dieu station in Lyon and the Stazione Centrale in Milan between 2002 and 2004. It goes without saying that two cases cannot possibly enable to draw general conclusions about third sector organizations or about the larger issues tackled in this work. The function of the cases presented here is to show in practical terms what the questions posed refer to, and to identify the empirical mechanisms, for which it is safe to assume that there is no reason why they would not occur in other contexts. The qualitative survey essentially consisted of making observations and conducting interviews, mainly with the railway companies, the police and social workers, on each site (30 interviews in the Lyon station, 18 in the Milan station). Collecting all these points of view enables us to produce a synthesis that is different from the sum of the individual points of view of each actor. The survey should therefore lead to "a simplification of reality, partially at odds with the ordinary interpretations and visions of the actors in the context of the action studied" (Friedberg 1993: 317). The logic of the comparison between France and Italy is not to control cultural or institutional variables, but rather to move away from the framework of the nation state in order to identify mechanisms that are not specific to a particular country. It is important to point out that the data from the Italian case and the French case are not of the same nature. Some 80,000 people pass through the railway station in Lyon every day, and the facts investigated relate to some ten homeless people, over a period of two years. 300,000 people pass through the Milan railway station every day; and the events take place between 1993 and 2004, and they relate to a significant and diverse marginalized population (drug addicts, homeless people and immigrants). This is why the Italian case will receive more attention in the developments to follow.

\section{Managing unintended consequences}

Since 1991, a Directive of the European Commission has encouraged member states to embark on a process of opening the railway sector up to competition. This opening up involves on the one hand an end to national monopolies over railways, and on the other privatization of national companies. Public railway companies tend to be loss-making and highly dependent on subsidies (Marlot 2004, Guélaud 2002). Traditionally, these companies invested more in the trains, which are the core of their business, than in the stations, which were for a long time viewed as functional spaces in which to assemble passengers at points of convergence before getting them onto the trains (Sander 1996). This lower investment in railway stations had contributed to their dereliction. The poor reputation of railway stations and the people regarded as undesirables that they attract became a particular problem for the railway companies when it came to opening them up to competition. The SNCF set up a stations department, and the FS set up the Grandi Stazioni project in order to carry out renovation projects for their railway stations. The idea was to introduce mini shopping centres in order to take advantage of the potential customers passing through the stations every day. These shops, in their turn, need security, which the railway companies, to whom they pay rent, had to provide. In the medium term, the railway companies rely on the presence of shops to contribute to the redefinition of the railway station. From this viewpoint, the presence of marginalized people is doubly detrimental to the railway companies' profitability: the homeless indirectly convey a negative image 
of the world of the train, and by reducing their attractiveness to businesses (the rent the shopkeepers pay), they directly affect the profitability of these companies. In order to get rid of marginalized people, the companies initially contemplated resorting to coercion.

\section{The limitations of police work}

In the French case, the SNCF thought first of using its internal security service, Surveillance Générale (Suge). Its work would have consisted of harassing the homeless in such a way that would deter them from hanging around in the precincts of the station. This solution came up against legal constraints and image problems. On the one hand, sitting down in a railway station is not legally prohibited, and the police or officials of the Suge can only punish criminal offences, such as forcing children to beg. On the other hand, a railway station is a public space, subject to the gaze of travellers, who might protest against any violent intervention. It is not in the railway company's interest to have a crowd form and disrupt the flow of people. An SNCF executive therefore convinced his management to find a non-coercive solution and call upon social workers.

In the Italian case, the police was the sole security actor from 1993 to 1999. In 1992, the Lega Nord (Northern League) won the municipal elections, and brought pressure to bear on finding a policing solution for the railway station. In 1993, corrupt policemen were removed from the station. "Major operations" then began: police raids at night, using police vans, to arrest a maximum number of marginalized people, deport immigrants and imprison drug dealers.

(And what was that like?) Heavy patrols. We had these non-EU nationals ${ }^{1}$, so with around thirty policemen, we arrested all the non-EU nationals, marginalized people and undesirables, we put them in a police van, and they were all taken to the police station, where they were charged with an offence. (Police Superintendent, Italian station)

The criminal networks were weakened and drug trafficking was pushed back into the adjacent streets, but the experience of users, travellers and local residents, did not change: the railway stations still attracted many marginalized people. This is where police action finds its limitations: the police can arrest offenders, but they have neither the means nor is it their mission to deal with poverty, which has no legal definition. The police simply cannot do the social work that is required to take care of marginalized people.

Even an idiot can understand that someone who sleeps in a shelter at night will not be dossing in the street with a blanket and a bottle of beer, that someone who has been given a meal will not go off and steal food, that someone who has been given shoes will not walk around barefoot, and that someone who has been given a clean $t$-shirt, creates less of a disturbance than if he's wearing a t-shirt covered in blood. (...) These are ordinary examples. Helping people to get access to a health

1 The Italian word to designate (poor) immigrants is "extracomunitari", literally "non-EU national", which can refer to white European (such as Ukrainians), Asian, South American or African immigrants. 
system, helping them in their dealings with the authorities, avoids other problems. You protect the fringes at risk. Educating prostitutes about cleanliness, washing, avoids them passing on diseases. (Social worker 2, Italian station)

In Milan as in Lyon, it is not so much benevolence towards the most vulnerable people as the limitations (perceived and real) of the police solution that motivated the municipality and the railway companies to turn to social policies.

\section{The unintended consequences of social policies}

Turning to social policies to produce order has many advantages in practical and symbolic terms. This strategy nevertheless raises the problem of its own unintended consequences. The issue here is not to judge the appropriateness of the idea of the unintended consequence of assistance or its intrinsically reactionary nature (Somers and Block 2005), but to look at it from the point of view of the promoters of "social" solutions, particularly within the railway companies. From the point of view of the actors who wish to reduce the nuisance caused by marginalized people, an unintended consequence is an incentivising structure set up to disperse marginalized people which ends up attracting more than it disperses.

The promoters of non-repressive solutions at the SNCF, assumed to be the most concerned both about the interests of the homeless and about the most humane possible treatment of poverty, are acutely aware of the problem of assistance. The experience of the major Parisian railway stations shows that the distribution of food (from soup kitchens) attracts large numbers of the needy.

There are unintended consequences in the actions you take. When you begin to welcome people... At the soup kitchen in *** station, there were 100 of them to begin with, and in the end it was serving 700 meals a day. It brings people in and then they stay. (...) Bringing in people to organize meals in the station is counterproductive. (National manager of Mission Solidarité, SNCF, French station)

Food distribution was then rejected, the community organizations were in agreement with this, it was rejected because it creates support centres. (Regional manager of Mission Solidarité, SNCF, French station)

The actors of the railway company in the Milanese case were also well aware of the limitations of the strategy which consists of funding community organizations.

Social aid alone is not enough, it's like feeding stray dogs and cats, it doesn't solve the problem. You can't get rid of them, so you move them, but it's not simply a question of moving them, you have to organize them (Security manager, Grandi Stazioni, Italian station)

For the organizational actors or those ideologically close to them (whose practical interests and values are to promote "social" solutions), the issue of unintended consequences is neither a matter of making the poor aware of their 
responsibilities, nor is it a way of putting the problems of the railway company above the wellbeing of marginalized people: it is a matter of the ethics of responsibility. If a mechanism for social aid is overloaded, it is stopped, and no one benefits from it. It is better for the mechanism to benefit a few rather than to benefit no one. To minimize these unintended consequences, the railway companies count on the police or on their security service. Implementing operations with community organizations implies not creating a precedent which makes the homeless of the region think that hanging around in the station is the best way to find long-term institutional aid. In other words, it is about helping the homeless, in order to make them leave, without attracting others: "to get them out of poverty (and out of the station, too)" (Soutrenon 2001).

Consequently, the issue is one of coordination between railway companies, police and community organizations. All the actors have different values, objectives and methods. The values of the police and social workers are often conflicting, some valuing "repressive" policies and others "social" policies. But awareness of the intrinsic limitations of the former and the unintended consequences of the latter leads these actors to work together. For example, the Fratelli di San Francesco (an organization which manages the Help Center) need the police when a marginalized person becomes threatening, but the police often need the Fratelli to take care of a minor in their communities when the law prohibits any criminal action. This situation of interdependency leads the police to tolerate certain illegal practices of the Fratelli, such as helping people who are in the country illegally.

The cops know that the Fratelli feed and house undocumented immigrants, but they don't carry out a raid to increase arrests, because they are the first to ask the Fratelli to take care of mass poverty when they need it, such as when there is a humanitarian disaster. So, it's an informal agreement: "we take your needy when necessary, and you don't come here hassling us". (Social worker 3, Italian station)

Coordination is carried out by the railway companies. They fund the community organizations so that they can carry out services that suit the interests of the railway companies. In the next section we are going to look in detail at the missions that these organizations are asked to carry out by the railway companies.

\section{Managing the marginalized}

\section{The Lyon station: breaking up the focal point, rehousing the homeless}

In the Lyon station, the SNCF's objective was to rid the railway station of the presence of homeless people. Rather than entrusting this mission to security officers or bringing in the police, the SNCF set up a "monitoring committee" with the Ministry of Health, the Municipality and the police and decided to call upon the services of a charitable organization to resolve the problem.

Initially, this involved carrying out a sociological expert appraisal - the speciality of the organization - taking two to three months. This expert appraisal was conducted by social workers and was also designed to establish contact with the homeless. From April to June 1999, social workers went out to meet the 
homeless to gather information about them, establish contacts and create a relationship of trust. The social workers observed that the majority of the homeless - around a dozen - came and went, never staying in the station for long. They sometimes stayed for no longer than an hour. The nuisance they caused depended on their level of alcoholism and on the ups and downs of their relationships. The social workers realized that the homeless were organized around one of them, a man of around fifty who had spent 19 years in the station and who "lived" in the car park. Making the most of his perfect knowledge of the station and the cordial relations he had managed to establish with the police, tradesmen and SNCF employees, he had occupied two parking spaces with his belongings for so long that no one even thought of making him leave. He offered to let homeless people who came to the railway station stay for a while in "his" space for a small sum, promising them relative peace and quiet.

The conclusion we came to was that we had to break the hard core. I really don't like talking like that but it was necessary to break the hard core, the hard core consisted of two people, who were living in the car park under the hotel, (...) that's where the homeless bloke lived, so he controlled, he controlled, and he even sold spaces to people, "come and sit by me, don't worry, I know the cops, just give me a euro, two euros," well, at the time it was ten francs, and anyway .... we said "we have to break this thing". Well by break I mean make the guy who was living there permanently agree to having treatment. And the guy agreed to go away for treatment for alcoholism. (Regional manager of Mission Solidarité, SNCF, French station)

Secondly, the social workers had to put forward solutions for rehousing the homeless, in order to get them to leave the railway station for good. The social workers were faced with an obligation to achieve results from their partners in the local authority, the police and the SNCF. If they did not manage to rehouse the homeless, if they did not manage to establish a relationship of trust with the homeless such that they would agree to leave the station, the police and the Suge would resort to coercion to "break up the focal point" - the expression used by the institutional actors to refer to the removal of the homeless.

Convincing the homeless to leave the station is more complex than it might appear, because they develop routines and social interactions in the premises that they frequent, and they refuse in any case to be housed in a hostel, where the living conditions are very restrictive and where dogs are not allowed. Rehousing in a flat allows dogs to be taken into consideration, but involves skills which the homeless who are most accustomed to living in the street have lost, such as keeping it clean, dealing with leaks, handling gas points with care, using the toilet. The social workers finally decided to ensure the departure of the most longstanding homeless person in the station, the one who rented his space to others, in order to prevent others moving in afterwards. They convinced the old man to go for treatment for alcoholism and helped him move into a small apartment. The SNCF immediately installed wire netting around the place the homeless had been using and the station's security officers carried out a systematic policy of discouraging new arrivals. The other homeless people agreed 
to be rehoused. In the winter of 1999-2000 new homeless people arrived in the station, but did not stay.

\section{The Milanese station: moving marginalized people away in the long- term}

In the Milan station, it was less a case of rehousing a few homeless people (as in the French station) than of controlling the nuisance caused by the presence of hundreds of marginalized people. There are many community organizations each playing a role in managing the poverty the railway station attracts. The community organizations, by offering services to marginalized people, create a relationship of dependence and personalization of relations which cannot fail to stabilize these populations which potentially put order in the station at risk. The function of control played by the community organizations is the keystone of the security policy of the FS group, which has managed to take advantage of the funding granted by the Municipality, according to two methods: the dispersal of marginalized people and the accumulation of information about them.

Because the station continued, in spite of police repression, to draw marginalized people who frightened travellers, the various constituents of the Italian railway company coordinated with each other to use the station's Help Center as a centre for dispersing marginalized people throughout the area. The reasoning was as follows: since the poor are going to come to the station in any case, and since in any case it is not possible to make them leave without offering them an alternative, you might as well accept the inevitable presence of marginalized people in order to better channel them towards the areas where they cause less nuisance. This solution requires having free spaces available which are able to take the marginalized people. The Help Center only carried out its function of dispersal on condition that it could offer the marginalized people spaces in refuges. For a person in need, the decision to leave the support networks and solutions offered by the railway station can only be motivated by a prospect that is at least comparable, i.e. another form of aid. Now, like all the national railway companies, the FS group is historically a large property owner. And, like everywhere in Europe, rail transport has declined considerably since the Second World War. RFI (the infrastructure and network branch of FS) owns a number of more or less abandoned signal boxes, small stations, warehouses and sheds. The smallest stations are increasingly operated unmanned. In Lombardy, $45 \%$ of stations are fully automated. These railway infrastructures are often occupied illegally by groups of immigrants. Police operations against this phenomenon have no long-term effect as the squatters always come back. When a facility has been squatted and the police have intervened, it costs the RFI on average $€$ 250,000 to restore the property to its initial value. For RFI, these spaces might therefore be better used, hence the idea of having them run by community organizations in order to protect them against illegal occupation. In Lombardy 80 railway stations are now run in this way. Out of the 1500 automated stations (but which also have travellers passing through) in Italy, 400 are run by community organizations. The organizations do well out of this, since they are given premises free of charge and are legitimized in their action; and the railway company also does well out of the arrangement, since the marginalized people are settled and kept under control, out of sight of travellers. 
But the ambition of the authorities does not boil down simply to the dispersal of the marginalized. Grandi Stazioni's plan is to make the most of the grassroots knowledge of the organizations in order to gain a better understanding of these marginalized populations, isolating those who are potentially dangerous and where applicable carrying out targeted repressive campaigns.

It is therefore a synergy. The community organizations that are working in the station, who come to the aid of the homeless, have signed an agreement with us to improve security. They make their knowledge of the people they mix with available to us, distinguishing criminals, dealers and violent people from the homeless. With the community organizations, we can pinpoint dangerous individuals, in order to cure the station once more (...) There is an agreement between the community organizations, the city, the station and the police to improve security. Standardized forms have been produced to improve our knowledge of the homeless and the marginalized and put those who behave badly into prison. It all revolves around these forms. And as Grandi Stazioni is giving these community organizations premises ... (Security manager, Grandi Stazioni, Italian station)

The railway company, which provides the community organizations with premises and funding, expects its community organization interlocutors to give it in exchange individualized information on the marginalized people with which they are in daily contact. The work of the railway company is therefore to integrate the work of the community organizations into the station's security policy by building up the coordination between the community organizations and the police, so that police repression and social work are no longer seen as being in opposition, and to make the most of the skills of both to further the conversion of the station into an attractive area for its customers ${ }^{1}$.

The work of the community organizations stresses the complexity of managing marginalized people in railway stations. Bearing in mind the legal constraints and the intrinsic attractiveness of stations to marginalized people, a policy based purely on policing is not effective. To achieve its ends, the railway company is forced to practise, through community organizations, a subtle game of incentives and sanctions. From a more strictly analytical viewpoint, it is possible to identify two social control mechanisms at work in these social policies: (a) the use of incentive and disincentive measures which affect or channel behaviour, and (b) the establishing of relationships of dependence which keep a check on the beneficiary of these social policies. In both stations, the charitable organizations are using incentives to get marginalized people to leave the station. In the Milan station, the ongoing support provided for marginalized people makes them more predictable as they are more dependent on the aid.

\footnotetext{
${ }^{1}$ At the time of the research, this project had not yet been implemented. It is clear that for ideological and religious reasons, community associations are reluctant to provide this information, particularly to the police (Navarini et al. undated). The question is twofold: can the railway company force the community associations to cooperate? What area of doubt are the community associations in a position to maintain?
} 
The active cooperation of the community organizations in the dispersal of marginalized people shows to what extent the boundary between social policy and security policy is empirically tenuous: a dichotomous conception of these two concepts is inappropriate. This cooperation also creates a tension between the objectives of the community organizations ("tackling social issues") and those of the railway companies ("getting rid of marginalized people"). Does this mean that the community organizations are instruments of social control? In the next part we are going to try to show the opposite by highlighting the notion of agency.

\section{Managing legitimacy and the interplay of exploitations}

The specific legitimacy of community organizations is based on their capacity to present themselves as actors disinterested in material profit (Gadrey 2000) and motivated by solidarity and compassion rather than opportunism. People imagine the world of community organizations to be swimming with charismatic figures and positive values such as solidarity and self-sacrifice. A significant part of social science literature on the third sector and civil society also uses this discourse of praise. Within it the non-profit sector is described as a major social innovation (Salamon 1995, Salamon and Anheier 1997, Anheier and Salamon 1998, Salamon et al. 1999), regarded as remedying the problems deriving from capitalism (Fourel 2001, Jeantet 2006, Laville and Cattani 2006, Laville et. al 1997, Laville 2000) and renewing democracy (Putnam 2000, Chanial 2001, Evers 2000) ${ }^{1}$. This specific legitimacy is the principle that motivates volunteers to work for community organizations, which are able to operate thanks to the normative commitment of their members (Etzioni 1964).

This same legitimacy is indispensable in the relationship of community organizations with their institutional partners. The Municipality and the railway company are all the more inclined to fund community organizations if these organizations are able to bring their legitimacy to bear in such a way that this legitimacy reflects on those providing the funding. Funding a charitable organization shows that one is concerned about human issues and not only about financial profit. Community organizations are well aware that they are selling their legitimacy as much as their labour force. They are all the more aware of it because, as organizations, they are faced with the problem of keeping going or even of survival. Because community organizations are organizations, their first imperative, like all organizations, is to survive (Hannan and Freeman 1977, Carroll 1984, Hall 2002). In order to keep going, organizations must cooperate with actors who have the means for their survival. Marwell (2004) has shown for example how community organizations providing home help services in two Hispanic neighbourhoods of New York were directly involved in local electoral clientelism. The community organizations receive subsidies from local councillors. The local councillors want to be re-elected. The community

\footnotetext{
${ }^{1}$ Empirical work on community associations is distinctly less lyrical. It stresses the conflicts and the power relations within community associations (Laville and Sainsaulieu 1997a), and the ups and downs of their daily operation, of their professionalization and the nature of their funding (Haeringer et al. 1997, Laville and Sainsaulieu 1997b). Besides, Salamon (1995), concerned at seeing rather too optimistic a literature developing about the capacity of community associations to "change people's lives", warned over ten years ago against the romanticization of the third sector in literature. See also the critical discussions of Mayer (2003) and Pirotte (2007).
} 
organizations want to go on helping people. So it is in the interest of local councillors to subsidise the community organizations that are favourable to them, at the expense of those that are not, and to use the influence that they have in the population to help them be re-elected. The community organizations have an interest in stabilizing their funding and therefore in getting the politicians who grant them subsidies elected. In a context in which each community organization depends on funding that is always temporary, the survival of the organization depends on its capacity to be able to continue to sell its services. As a result the relations between community organizations and those funding them involve mutual exploitation, the sophistication of which is at odds with the disinterestedness on which their legitimacy is based.

Almost all volunteers, social workers and community organization managers who work on behalf of the homeless and drug addicts are firmly convinced that the destitute people at the station are worthy of respect and consideration. The main community organizations are part of the Christian-social movement and almost all of the social workers are firmly progressive. They consider marginalized people to be victims of an unfair economic order and of an egotistical society. Working in a charitable organization almost always implies favouring social aid over repression in the treatment of poverty. From that, one might expect community organizations to show hostility towards the intentions of the Municipality or Grandi Stazioni: for do these bodies not view solidarity as a means in the service of security?

On the contrary, the security intentions of the Municipality and Grandi Stazioni are resources for the community organizations in the railway station. Rather than holding on tightly to a purely charitable process, they intend to benefit from the opportunities - material and symbolic - that the present situation offers, by explicitly linking social aid and improvement in security in their applications for funding or premises. The theme of security as a principle justifying the collective usefulness of social work is used by community organizations as a code of communication with the various components of the railway company.

Our community organizations are involved in aid projects on

behalf of the fringes of profound marginality which are often represented in the form of social concerns and danger to citizens, and this without doubt links the consideration with the security aspect. (...) Our community organizations have effectively shown in recent years that the action of aid, help and social protection of the fringe groups at greatest risk, accompanied by the equally necessary action of prevention, security and control by the forces of order, are the best conditions through which one can effectively deal with the problems related to profound social marginality, even on the fringes most at risk, with an undoubted benefit to citizens. ${ }^{1}$

The managers of community organizations are obviously convinced of the collective usefulness of their work but tend to view the question of security as secondary within an overall issue in which the priority is to come to the aid of poor people whose lives are in danger. Justifying the usefulness of their work

\footnotetext{
${ }^{1}$ Undated document from a group of community associations working at the station, entitled "Solidareta e sicurezza".
} 
from the security point of view therefore falls within the perspective of a cynical and opportunistic use of the situation to their own advantage.

In a meeting with the Lega Nord, when they ask us what we would do if we found a kid who had run away from Sicily and who turned up [at the station], we don't say "We did a great thing, we returned a kid to his parents," we say "we removed a criminal danger from the streets of Milan" (laughter). (Social worker 2, Italian station)

The community organizations that sell their legitimacy in order to collaborate with security policies are not mere victims: they have a capacity for agency. They benefit from their usefulness to the municipality or the railway company in order to get funding and they intend to use their margin for manoeuvre at local level to maximize the social dimension of their mission to the detriment of the security dimension. But they are playing with actors who are no less pragmatic; in the game of mutual exploitation, they can also come out the losers. The experience of other partnerships are the proof of this: charitable organizations are regularly brought in by the public authorities to take part in joint operations with the forces of law and order (state or municipal) in the course of which the presence of these community organizations appears to be to act as a "social guarantee", the "humanist" justification for a project which is not humanist in nature.

On Place des Terreaux, we were exploited much more... We played the role of social guarantee for cleaning up the Place des Terreaux. We were really manipulated... (Social worker, French station)

In the case mentioned by this interviewee, the social workers were not informed about police operations carried out against the marginalized people whose trust they were supposed to have gained. This shows that the exploitation works two ways: on the one hand the community organizations exploit the theme of security and the bad conscience of certain decision-makers in order to keep their sources of funding going with projects at the margins of social work; on the other hand, the public authorities and private companies exploit the community organizations by making them play the role of "social guarantee" when problems are controversial. As there are many community organizations and their funding is insecure, it is plausible that they are being exploited more often than they exploit more stable actors such as the public authorities or large companies.

\section{Conclusion}

Faced with the problem of marginalized people in railway stations, the railway companies have turned to charitable organizations to find a more satisfactory solution than mere repression. The notion of management (of unintended consequences, of marginalized people and legitimacy) enables them to exploit the subtle power relations that come into play in the implementation of these policies. In Lyon as in Milan, the community organizations have to manage the unintended consequences of their own work, both to satisfy the demands of their employer, but also so that they can continue to offer attractive services. They set up incentive structures for marginalized people in order to make them comply with the expectations defined by the railway companies. These incentive 
structures are not by nature coercive, and for this reason the community organizations cooperate with the police. They set up a game in which there is something for everyone, marginalized people and railway companies. But the community organizations are managing not only marginalized people, they are also managing their legitimacy. In short, they participate in the philanthropic, "social" (as opposed to "security") legitimation of the railway companies, at the risk of putting their own legitimacy in danger by participating in the commercial upgrading of stations.

A pragmatic strategy for the railway companies therefore implies reconciling police operations with social treatment in a bid to limit conflicts and make the space as pleasant as possible for users - but this requires compromises to be made with a fundamentalist conception of "security". Symmetrically, speaking of "solidarity" in reference to social work seems improper given the exploitation of this solidarity: dispersing marginalized people, making the station better for business, satisfying the demands of voters. The community organizations are not taken in by this policy but they do benefit from the opportunities it provides to ensure the survival of their organization. For the management of community organizations and for the volunteers, the desirable objective would be the disappearance of poverty as an insult to humanity; for Grandi Stazioni and the SNCF, it is a more modest matter of reducing the visibility of poverty in the spaces around the railway station in order to minimize damage to business. But all the managers of the various components of the FS Group and the SNCF know that there will always be marginalized people and that the railway stations will always attract them.

In this game the central backers are the railway companies, and the central service providers are the community organizations. The state remains a notable actor due to the involvement of the police, but it is practically absent from the social policies. In France, its share of the funding of community organizations through its local public services, in a project that it has not initiated and does not run, is minor; in Italy, it is only marginally involved in the way the operation is funded.

The approach taken allows two deceptive conceptions of the relation between social policies and security policies to be kept apart. On the one hand, fieldwork shows that the management of marginalized people by community organizations falls within a continuum between social policy and criminal policy, in the middle of which the boundaries are vague. The dichotomous opposition between social policy and security policy makes no sense; the irenic hypothesis, which idealizes ("humane" and "just") social policies by opposing them to ("repressive" and "violent") security policies, ignores this complexity. On the other hand, within this continuum, the community organizations are trying to use their agency at local level to ensure the "social" nature of their mission, which is to participate in the upgrading of the station. This capacity for agency contradicts the malefic hypotheses according to which social policies "only" carry out a more insidious form of social control.

There remains a paradox. To get beyond the opposition between the irenic hypothesis and the malefic hypothesis, it is necessary to differentiate 
between emic concepts (those of the actors) and etic concepts (those of sociological analysis). As it happens, it is vital to understand the meaning and value that the "social policy" and "security policy" categories have for the actors concerned, if you want to analyze the policies implemented in the railway stations of Lyon and Milan. But claiming the superiority of science over common sense does not do the actors justice: the strategies used by the actors testify to a perfectly practical analysis of the real challenges (not to mention the academic translation of the irenic and malefic hypotheses). All in all, this article shows to what extent the actors involved are pragmatic, competent and insightful, and capable of understanding the nature of power relations from a practical point of view.

\section{Bibliography}

Anheier H.K and L.M. Salamon 1998, The Nonprofit Sector in the Developing World. A Comparative Analysis, Manchester: Manchester University Press, "Johns Hopkins Nonprofit Sector Series"

Austin M.J., 2003, "The Changing Relationship Between Nonprofit Organizations and Public Social Services Agencies in the Era of Welfare Reform", Nonprofit and Voluntary Sector Quarterly, 32 (1), March, pp. 97-114

Bowie K. 1996, "De la gare du XIXe siècle au lieu-mouvement. Évolution ou rupture?", Annales de la recherche urbaine, No. 71, June, pp. 14-23

Carroll G.R. 1984, "Associational ecology", Annual Review of Sociology, vol. 10, pp. 71-93

Chanial P. 2001, "Société civile, société civique? Associationnisme, libéralisme et républicanisme", in Jean-Louis Laville (ed.) 2001, Association, démocratie et société civile, Paris: La Découverte : MAUSS , pp. 141161

Cohen S. 1979, "The Punitive City: Notes on the Dispersal of Social Control", Contemporary Crises, 3 (4), pp. 339-63

Colombo E. and G. Navarini 1999, Confini dentro la città. Antropologia della Stazione Centrale di Milano [Fronteers within the city. Anthropology of Milan's Central Station], Milan: Guerini Studio,

Crozier M., E. Friedberg 1977, L'acteur et le système. Les contraintes de l'action collective, Paris: Seuil, "Points Essais"

Della Porta D. and M. Andretta 2001, "Movimenti sociali e rappresentanza: i comitati spontanei dei cittadini a Firenze" [Social movements and representation: Spontaneous citizen's committees in Florence], Rassegna Italiana di Sociologia [Italian Review of Sociology], 42 (1), pp. 41-76

Dodenhoff D. 1998, "Is Welfare Really about Social Control?", Social Service Review, Vol. 72, No. 3, September, pp. 310-337

Donzelot J. 1977, La police des familles, Paris: Minuit

Durman E. 1973, "Have the Poor Been Regulated? Toward a Multivariate Understanding of Welfare Growth", Social Service Review, 47 (3), September, pp. 339-359

Emirbayer M. and A. Mische 1998, "What Is Agency?", American Journal of Sociology, Vol. 103, No. 4, Jan., pp. 962-1023

Emirbayer M. and J. Goodwin 1994, "Network Analysis, Culture, and the Problem of Agency", American Journal of Sociology, Vol. 99, No. 6, May, pp. 1411-1454 
Etzioni A. 1964, Modern Associations, Englewood Cliffs, N.J.: Prentice-Hall, "Foundations of modern sociology series"

Evers A. 2000, "Les dimensions sociopolitiques du tiers secteur Les contributions théoriques européennes sur la protection sociale et l'économie plurielles", Sociologie du travail, 42 (4), pp. 567-585

Fourel C. (dir.) 2001, La nouvelle économie sociale. Efficacité, solidarité, démocratie. Paris : La Découverte / Syros

Friedberg E. 1993, Le pouvoir et la règle. Dynamiques de l'action organisée, Paris: Le Seuil, "Points Essais"

Gadrey J. 2000, "Le tiers secteur comme objet d'étude: quel objet, quelles études? Quelques commentaires sur les contributions précédentes", Sociologie du travail, 42 (4), pp. 601-606

Guélaud C. 2002, "La SNCF: une stratégie de croissance, un imaginaire du decline", in P.-É. Tixier (dir.), Du monopole au marché. Les stratégies de modernisation des entreprises publiques, Paris: La découverte, "Textes à l'appui"

Haeringer J., J.-L. Laville and R. Sainsaulieu 1997, "Introduction”, in J.-L. Laville and R. Sainsaulieu, Sociologie de l'association, Paris: Desclée de Brouwer, "Sociologie économique", pp. 15-32

Hall R.H. 2002, Associations. Structures, Processes, and Outcomes, Upper Saddle River, NJ: Prentice Hall, 8th edition

Hannan M.T. and J. Freeman 1977, "The population ecology of organizations", American Journal of Sociology, Vol. 82, No. 5, pp. 929-964

Jeantet T. 2006, Économie sociale. La solidarité au défi de l'efficacité, Paris: Documentation française

Laville J.-L. 2000, "Le tiers secteur. Un objet d'étude pour la sociologie économique", Sociologie du travail, 42 (4), pp. 531-550

Laville J.-L. and A.D. Cattani 2006, Dictionnaire de l'autre économie, Paris: Folio

Laville J.-L. et al. 1997, "Associations et société,, in J.-L. Laville and R. Sainsaulieu, Sociologie de l'association, Paris: Desclée de Brouwer, "Sociologie économique", pp. 317-372

Laville J.-L. (ed.) 2001, Association, démocratie et société civile, Paris: La Découverte, MAUSS

Laville J.-L. and R. Sainsaulieu 1997a, Sociologie de l'association, Paris: Desclée de Brouwer, "Sociologie économique"

Laville J.-L. and R. Sainsaulieu 1997b, "Les fonctionnements associatifs", in J.-L. Laville and R. Sainsaulieu, Sociologie de l'association, Paris: Desclée de Brouwer, "Sociologie économique"

Marlot G. 2004, "La déréglementation du transport ferroviaire européen", Regards sur l'actualité, n³06, December, pp. 59-72

Marwell N.P. 2004, "Privatizing the Welfare State: Nonprofit Community Based Organizations as Political Actors", American Sociological Review, 69 (2), pp. 265-291

Mayer M. 2003, "The Onward Sweep of Social Capital”, International Journal of Urban and Regional Research, 27 (1), pp. 110-132

Navarini G., M. Palmigiani and S. Tosi, undated, "Marginalità e interventi nella Stazione Centrale di Milano. I problemi, la situazione, le azioni in corso" [Marginality and interventions in Milan's Central Station: Problems, situation and current actions], in Le persone senza dimora e $i$ 
luoghi dell'esclusione sociale: le stazioni ferroviarie. Un progetto transnazionale per conoscere e definire azione volte a combattere l'esclusione sociale [Homeless people and the places of social exclusion: the railway stations. A transational project for knowledge and to define actions to fight social exclusion], Research report for CARITAS and the European Union.

O'Connor J., 1973, The Fiscal Crisis of the State, New York: St.Martin's Press

O'Looney J. 1993, "Beyond Privatization and Service Integration: Organizational Models for Service Delivery", Social Service Review, Vol. 67, December

Offe C. 1984, Contradictions of the Welfare State, London: Hutchinson

Pirotte G. 2007, La notion de société civile, Paris: La Découverte, "Repères"

Piven F.F. and Richard A. Cloward 1993, Regulating the Poor. The Functions of Public Welfare, New York: Vintage, $2^{\text {nd }}$ edition

Platt A. 1977, The Child Savers, Chicago: University of Chicago Press

Poletti C. 2003, "La partecipazione dei comitati di cittadini alle politiche di sicurezza in ambito urbano: una ricerca sui comitati di cittadini modanese" [The participation of citizen's committees to security policies in the urban context: A research on Modano's citizen's committees], Dei delitti e delle pene, No. 3, pp. 285-328

Putnam R.D. 2000, Bowling Alone. The Collapse and Revival of American Community, New York, NY: Simon and Schuster Paperbacks

Ribeill G. 1996, "Les métamorphoses de la grande gare française", Annales de la recherche urbaine, No. 71, June, pp. 55-65

Salamon L.M. 1993, "The Marketization of Welfare: Changing Nonprofit and For-Profit Roles in the American Welfare State", Social Service Review, vol. 67, No. 1, March, pp. 16-39

Salamon L.M. 1995, Partners in Public Service: Government-Nonprofit Relations in the Modern Welfare State, Baltimore, MD: Johns Hopkins University Press

Salamon L.M. et alii 1999, Global Civil Society. Dimensions of the Nonprofit Sector, Baltimore, MD: The Johns Hopkins Center for Civil Society Studies

Salamon L.M. and H.K Anheier 1997, Defining the Nonprofit Sector. A CrossNational Analysis, Manchester: Manchester University Press, "Johns Hopkins Nonprofit Sector Series"

Sander A. 1996, "Des lieux-mouvements bien singuliers", Annales de la recherche urbaine, No. 71, June, pp. 45-53

Sewell W.H. Jr 1992, "A Theory of Structure: Duality, Agency, and Transformation”, American Journal of Sociology, Vol. 98, No. 1, Jul., pp. 1-29

Shapiro S.P. 2005, “Agency Theory”, Annual Review of Sociology, vol. 31, pp. 263-284

Smith S.R. and M. Lipsky 1993, Nonprofits for Hire: The Welfare State in the Age of Contracting, Cambridge, MA: Harvard University Press

Somers M.R. and F. Block 2005, "From Poverty to Perversity: Ideas, Markets, and Institutions over 200 Years of Welfare Debate", American Sociological Review, 70 (2), pp. 260-287 
Soutrenon E. 2001, "Faites qu'ils (s'en) sortent. A propos du traitement réservé aux sans-abri dans le métro parisien", Actes de la recherche en sciences sociales, Nos. 136-137, pp. 38-48

Trattner W.I. (ed.) 1983, Social Welfare or Social Control?, Knoxville: University of Tennessee Press

Van Krieken R. 1991, "The Poverty of Social Control: Explaining Power in the Historical Sociology of the Welfare State", Sociological Review, 38 (1), pp. $1-25$

Williamson O.E. 1975, Markets and Hierarchies: Analysis and Antitrust Implications, New York: The Free Press 